\title{
EFEKTIFITAS PERAN LEMBAGA PERLINDUNGAN SAKSI DAN KORBAN (LPSK) DALAM MELINDUNGI SAKSI TINDAK PIDANA GRATIFIKASI
}

\author{
Sofyan Rauf ${ }^{1}$, Hasjad $^{2}$, Sabri Guntur ${ }^{3}$ \\ Universitas Lakidende Unaaha \\ Email Korespondensi: hasjadhasjad8@gmail.com
}

\begin{abstract}
Abstrak
Tujuan Penelitian ini adalah mengetahui dan menganalisis Efektifitas Peran Lembaga Perlindungan Saksi dan Korban (LPSK) dalam melindungi saksi tindak pidana gratifikasi dan untuk mengetahui dan menganalisis upaya ideal peran Lembaga Perlindungan Saksi dan Korban ( LPSK) dalam melindungi saksi tindak pidana gratifikasi di masa yang akan datang. Penelitian ini menggunakan metode yuridis normatif dengan mengumpulkan data/ informasi melalui pertama, bahan pustaka primer yang berisikan pengetahuan ilmiah yang baru (mutakhir), pengertian baru dan fakta baru yang diketahui maupun gagasan atau ide. kedua bahan pustaka sekunder yang berisikan informasi tentang bahan primer. Hasil temuan penelitian, (1) Efektifitas Peran Lembaga Perlindungan Saksi dan Korban (LPSK) Dalam Melindungi Saksi Tindak Pidana Gratifikasi masih belum efektif disebabkan oleh masalah Internal dan Eksternal LPSK. Faktor internal; kurangnya Professionalitas TIM LPSK dalam menjalankan tugas melindungi saksi/pelapor tindak pidana gratifikasi, kurangnya sinergisitas dalam sekretariat LPSK sebagai tim kerja dalam melindungi saksi tindak pidana gratifikasi, kurangnya biaya/ anggaran akan ketersedian dukungan finansial yang memadai dalam melindungi saksi tindak pidana gratifikasi. Faktor Eksternal; Kurangnya hubungan yang bersinergi dan kerjasama yang kuat antara lembaga penegak hukum, instansi pemerintah yang terkait, organisasi masyarakat, dan pihak swasta sehingga dalam memberikan perlindungan dan rasa aman baik dalam tekanan psikis maupun fisik belum efektif, belum adanya LPSK didaerah-daerah sehingga dalam penanganan perlindungannya masih terkesan lambat dan tidak efektif karena segala proses perlindungan masih terpusat di jakarta. (2) Upaya Ideal Efektifitas Peran Lembaga Perlindungan Saksi dan Korban Dalam Melindungi Saksi Tindak Pidana Gratifikasi dimasa mendatang adalah adanya rumusan dan penjelasan Undang-Undang Perlindungan Saksi dan Korban Nomor 13 tahun 2006 dalam Pasal 1 ayat (1) yang menyangkut saksi dan mengatur tentang Saksi Gratifikasi pada bagian tersendiri, Pasal 5 tentang hak saksi dalam pemeriksaan dilakukan terpisah dengan terdakwa, Pasal 29 sampai Pasal 31 direvisi agar permohonan dan persetujuan saksi gratifikasi tidak dalam proses yang lama, jaminan pemberian perlindungan terhadap saksi tindak pidana gratifikasi tidak hanya dalam proses peradilan saja, melainkan juga setelah proses peradilan selesai. LPSK lebih meningkatkan sinergitas dan kerjasama terhadap lembaga penegak hukum, instansi pemerintah terkait, ormas, pihak swasta dan masyarakat baik dalam melindungi saksi/pelapor tindak pidana gratifikasi maupun mendapatkan informasi dari saksi/pelapor dugaan tindak pidana gratifikasi. Dibentuknya LPSK di daerah-daerah serta adanya sosialisasi tentang eksistensi LPSK khususnya dalam melindungi saksi tindak pidana gratifikasi sehingga menumbuhkan kepercayaan masyarakat terhadap kepastian perlindungan yang jauh dari ancaman dan intimidasi bagi saksi/pelapor tindak pidana gratifikasi.
\end{abstract}

Kata Kunci: Efektifitas, Peran Lembaga Perlindungan Saksi dan Korban (LPSK), Saksi Tindak Pidana Gratifikasi.

\section{Abstract}

The purpose of this study was to determine and analyze the effectiveness of the Role of the Witness and Victim Protection (Agency) in protecting witnesses the crime of graft and effort to investigate and analyze the ideal role Witness and Victim Protection Agency (Agency) protect witnesses in criminal 
acts of gratification in the future. This study used a normative method by collecting data / information through the first, the primary library materials containing new scientific knowledge (advanced) , new understanding and new facts that are known or thought or idea. two secondary library materials which contain information about the primary material. The findings of the study, (1) Effectiveness Role of the Witness and Victim Protection Agency (Agency) to Protect Crime Witness Gratuity is not effective due to the problem of Internal and External Agency. Internal factors; TEAM professionalitas lack Agency in carrying out the task of protecting the witness/complainant crime of gratification, lack of synergy within the secretariat of the Agency as a team work in protecting witnesses the crime of gratification, lack of cost/budget will be the availability of adequate financial support in protecting witnesses a criminal act of gratification. External factors; Lack of synergy and cooperation relations strong between law enforcement agencies, related government agencies, community organizations, and the private sector so as to provide protectin and security in both the psychological and physical pressure is not effective, the absence of the Agency in the regions so that the handling of protection still seems slow and ineffective because of all the protection process is still centralized in Jakarta. ( 2 ) Effectiveness of Efforts Ideal Role of the Witness and Victim Protection Protect Crime Witness Gratuity future is the formulation and explanation of the Witness Protection Act and Victim No. 13 of 2006 in Article 1 paragraph ( 1 ) concerning the witness and set about Witness gratification in a separate section, section 5 of the rights of witnesses in a separate examination conducted by the defendant, Article 29 to Article 31 petition and approval revised to witness gratuities not in the old process, guarantee the provision of witness protection for the crime of gratification not only in the judicial process alone, but also after the judicial process is completed. Agency further enhance the synergy and cooperation to the law enforcement agencies, relevant government agencies, community organizations, the private sector and the public good in protecting the witness / complainant crime of graft and obtain information from witnesses/complainants alleged criminal act gratification. The establishment of the Agency in these areas as well as the dissemination of the Agency 's existence, especially in protecting witnesses the crime of gratification that foster public confidence in the certainty of protection away from threats and intimidation for witnesses / complainants crime of gratification.

Keywords: Effectiveness, Role of the Witness and Victim Protection Agency, Crime Witness Gratification.

\section{PENDAHULUAN}

Reformasi mengandung arti perubahan untuk perbaikan. Maka, di dalam era reformasi ini perlu adanya penegakan supremasi hukum di segala aspek kehidupan, termasuk juga perbaikan kinerja lembaga-lembaga hukum dan aparat penegak hukum.

Korupsi sebagai suatu gejala sosial yang sangat merugikan keuangan dan perekonomian Negara serta pelaksanaan pembangunan nasional perlu di hadapi dan di atasi dengan usaha-usaha secara menyeluruh, integral dan simultan baik di bidang prevensi maupun di bidang represif agar supaya korupsi dapat diberantas dengan efektif dan efisien. Dewasa ini praktek korupsi menjadi semakin meluas dalam berbagai sendi pemerintahan di negara kita, seakan telah mengakar keberadaannya sehingga mengganggu roda pemerintahan serta melahirkan kerugian yang sangat besar terhadap keuangan dan perekonomian negara. Korupsi itu terjadi berulang-ulang karena telah menjadi kebiasaan dalam masyarakat untuk mempermudah dalam mendapatkan pelayanan dari pemerintah, dan sebaliknya pejabat pemerintah menggunakan kesempatan itu untuk memperoleh keuntungan 


\section{Sibcitie gourral}

Jurnal Ilmiah Bidang Sosial, Tkonomi, Budaya, Tekvologi, dan Pendidikan

yang sebesar-besarnya. Karena korupsi dipandang dapat mengganggu dan menghambat pembangunan nasional, merintangi tercapainya tujuan nasional, mengancam keseluruhan sistem sosial, merusak citra aparatur Negara yang bersih, berwibawa dan bertanggung jawab, dan yang pada akhirnya akan merusak kualitas manusia dan lingkunganya. Pada dasarnya tujuan dari pemberantasan korupsi di samping untuk memberi hukuman yang setimpal terhadap si pelaku (dengan harapan berefek preventif), juga untuk menyelamatkan dana negara yang dikorup guna dimanfaatkan dalam proses pembangunan.

Pemidanaan dalam perkara korupsi adalah memperhatikan / mempertimbangkan antara pidana penjara, denda dan barang-barang yang berhasil dirampas dari kerugian negara yang dapat dibuktikan, diperhitungkan untuk menentukan pidana uang pengganti maupun lamanya pidana penjara dan besarnya denda / subsider dendanya sekaligus. Seiring dengan berjalannya waktu para pelaku korupsi seolah tidak takut akan hukuman yang tertera dalam undang-undang tersebut dan malah semakin banyak para pelaku yang ditangkap oleh Komisi Pemberantasan Korupsi (KPK) sebagai salah satu institusi hukum dalam penegakan tindak pidana korupsi. Korupsi di Indonesia telah melibatkan banyak kalangan, baik pusat maupun daerah, di lembaga eksekutif, legislatif, yudikatif, dan tokoh masyarakat. Melihat kerugian yang ditimbulkan, maka korupsi dapat dikategorikan sebagai Regulatory offences atau delik yang menghalangi bahkan merampas hasil upaya pemerintah dalam mensejahterakan rakyatnya. Seiring dengan eksistensi korupsi dinegara kita yang semakin modern dan tak kunjung habis prakteknya, akibatnya korupsi pun menjadi hal yang biasa. Termasuk didalam kebiasaan melakukan pungutan tambahan atas proses pengurusan pembayaran pajak, perijinan, pengurusan pasport dan pengurusan KTP, maupun penerimaan baik berupa barang atau uang yang diterima oleh penyelenggara negara maupun pegawai negeri apabila ada kaitan langsung terhadap tugasnya. Maka penerimaan tersebut dapat dikategorikan delik "permintaan" atau dalam Undang-undang dikenal dengan istilah delik gratifikasi.

Praktik penegakan hukum seringkali diwarnai dengan hal-hal yang bertentangan dengan prinsip tersebut. Misalnya penganiayaan terhadap tersangkauntuk mengejar pengakuan, intimidasi, rekayasa perkara, pemerasan, pungutanliar dan sebagainya. Kemudian dari pihak korban juga merasakan diabaikan hak-haknya, antara lain dakwaan lemah, tuntutan ringan, tidak mengetahui perkembangan penanganan perkara, tidak menerima kompensasi dan tidak terpenuhi hak-hak yang lain. Selain tersangka dan korban yang sering diabaikan hak-haknya satu lagi yang berperan penting dalam mengungkap kebenaran suatutindak pidana adalah saksi.

Lembaga Perlindungan Saksi dan Korban (LPSK) secara yuridis formal mempunyai legitimasi karena dibentuk berdasarkan Undang-undang, namun secara sosial masih sering dipersoalkan. Bagaimana LPSK diperlukan sebagai bentuk kepedulian negara dalam melindungi warga negaranya, sangat tergantung pada situasi masing-masing kasusnya. sebagai Sebagai lembaga yang lahir dengan tugas utama memberikan perlindungan terhadap saksi dan korban, LPSK telah menunjukkan rekam jejak yang baik, seperti pada kasus Komjen Susno Duadji, Anggota Banggar Wa Ode Nurhayati, Mindo Rosalina Manulang. 
Beberapa perlindungan dilakukan terhadap saksi dan korban dalam tindak pidana gratifikasi, di mana dari perlindungan itu kemudian turut andil dalam menegakkan hukum demi mencapai keadilan. Akan tetapi selain perlindungan terhadap kasus gratifikasi suap ternyata akhir-akhir ini muncul gratifikasi model baru yakni seperti kasus gratifikasi seksual atau suap seks. Biasanya saat ini banyak pejabat mampu menahan agar tidak terlibat korupsi, namun tidak tahan dengan gratifikasi seksual seperti kasus yang menimpa Ahmad Fathanah, dimana pembuktian gratifikasi seksual tergolong sulit karena bersifat tertutup dan dilakukan oleh golongan elitesulit untuk di buktikan dan sangat dibutuhkan saksi dalam pengungkapannya. Hal ini sangat di butuhkan kehadiran dan peran LPSK dalam melindungi saksi tersebut. Menurut penulis seharusnya bangsa indonesia saat ini menjalankan sepenuhnya hukum nasional kita yang bersifat gotong royong Kekeluargaan, Toleransi yang berdasarkan perikemanusiaan, Anti Kolonialisme, anti imperialisme, anti feodalisme dalam segala manisfestasinya, dan pemersatu guna "nation building". Namun kenyataannya dalam peran dan fungsi dalam melindungi saksi tindak pidana korupsi khususnya gratifikasi, masyarakat menilai peranan LPSK dalam melindungi saksi / korban masih belum efektif, karena masih ada saja saksi yang mendapat ancaman / intimidasi dari luar serta belum terpenuhi secara maksimal hak-hak saksi dalam tindak pidana gratifikasi uang.

Berdasarkan uraian yang dikemukakan diatas, maka dapat dirumuskan beberapa masalah dalam usulan penelitian ini, adalah sebagai berikut Bagaimanakah Efektifitas Peran Lembaga Perlindungan Saksi dan Korban (LPSK) dalam Melindungi Saksi Tindak Pidana Gratifikasi saat ini? dan Bagaimanakah Upaya Ideal Peran Lembaga Perlindungan Saksi dan Korban ( LPSK) Dalam Melindungi Saksi Tindak Pidana Gratifikasi Di Masa Yang Akan Datang?

\section{LANDASAN TEORI Efektifitas}

Secara etimologi kata efektifitas berasal dari kata efektif, dalam bahasa inggris "effective" yang telah mengintervensi ke dalam bahasa Indonesia dan memiliki makna "berhasil". Dalam bahasa Belanda "effectieve" memiliki makna "berhasil guna". Efektivitas berasal dari kata efektif yang mengandung pengertian dicapainya keberhasilan dalam mencapai tujuan yang telah ditetapkan. Efektivitas selalu terkait dengan hubungan antara hasil yang diharapkan dengan hasil yang sesungguhnya dicapai. Menurut Effendy "Komunikasi yang prosesnya mencapai tujuan yang direncanakan sesuai dengan biaya yang dianggarkan, waktu yang ditetapkan dan jumlah personil yang ditentukan". Efektivitas menurut pengertian di atas mengartikan bahwa indikator efektivitas dalam arti tercapainya sasaran atau tujuan yang telah ditentukan sebelumnya merupakan sebuah pengukuran dimana suatu target telah tercapai sesuai dengan apa yang telah direncanakan. Menurut Susanto, "Efektivitas merupakan daya pesan untuk mempengaruhi atau tingkat kemampuan pesan-pesan untuk mempengaruhi" . Menurut pengertian Susanto diatas, efektivitas bisa diartikan sebagai suatu pengukuran akan tercapainya tujuan yang telah direncanakan 


\section{Sibcitie gourral}

Jurnal Ilmiah Bidang Sosial, Tkonomi, Budaya, Tekuologi, dan Pendidikan

sebelumnya secara matang. Menurut Agung Kurniawan dalam bukunya Transformasi Pelayanan Publik "Efektivitas adalah kemampuan melaksanakan tugas, fungsi (operasi kegiatan program atau misi) daripada suatu organisasi atau sejenisnya yang tidak adanya tekanan atau ketegangan diantara pelaksanaannya". Memperhatikan pendapat para ahli di atas, bahwa konsep efektivitas merupakan suatu konsep yang bersifat multidimensional, artinya dalam mendefinisikan efektivitas berbeda-beda sesuai dengan dasar ilmu yang dimiliki walaupun tujuan akhir dari efektivitas adalah pencapaian tujuan. Kata efektif sering dicampur adukkan dengan kata efisien walaupun artinya tidak sama, sesuatu yang dilakukan secara efisien belum tentu efektif.

\section{Peran}

Menurut Lawrence.M. Friedman "Peran adalah serangkaian perilaku yang diharapkan pada seseorang sesuai dengan posisi sosial yang diberikan baik secara formal maupun secara informal". Peran didasarkan pada preskripsi ( ketentuan ) dan harapan peran yang menerangkan apa yang individu-individu harus lakukan dalam suatu situasi tertentu agar dapat memenuhi harapan-harapan mereka sendiri atau harapan orang lain menyangkut peran-peran tersebut. Menurut Banton "peran" atau "role" sebagai "the boundaries and sets of expectations applied to role incumbents of a particular position, which are determined by the role incumbent and the role senders within and beyond the organization's boundaries" (batas-batas dan serangkaian harapan diterapkan dengan mapan dalam peran dan posisi tertentu, yang ditentukan oleh incumbent peran dan pengirim peran dalam dan di luar batasbatas organisasi ). Selain itu, Robbins mendefinisikan peran sebagai "a set of expected behavior patterns attributed to someone occupying a given position in a social unit" (serangkaian pola perilaku yang diharapkan dikaitkan dengan seseorang yang menduduki posisi tertentu dalam unit sosial ). Menurut Dougherty \& Pritchard dalam Bauer, teori peran ini memberikan suatu kerangka konseptual dalam studi perilaku di dalam organisasi. Mereka menyatakan bahwa peran itu "melibatkan pola penciptaan produk sebagai lawan dari perilaku atau tindakan". Lebih lanjut, Dougherty \& Pritchard mengemukakan bahwa relevansi suatu peran itu akan bergantung pada penekanan peran tersebut oleh para penilai dan pengamat terhadap produk atau outcome yang dihasilkan. Dalam hal ini, strategi dan struktur organisasi juga terbukti mempengaruhi peran dan persepsi peran atau role perception . Ditinjau dari Perilaku Organisasi, peran ini merupakan salah satu komponen dari sistem sosial organisasi, selain norma dan budaya organisasi. Di sini secara umum 'peran' dapat didefinisikan sebagai "expectations about appropriate behavior in a job position (leader, subordinate)" artinya "harapan tentang perilaku yang tepat dalam posisi pekerjaan (pemimpin, bawahan)". Ada dua jenis perilaku yang diharapkan dalam suatu pekerjaan, yaitu (1) role perception: yaitu persepsi seseorang mengenai cara orang itu diharapkan berperilaku; atau dengan kata lain adalah pemahaman atau kesadaran mengenai pola perilaku atau fungsi yang diharapkan dari orang tersebut, dan (2) role expectation: yaitu cara orang lain menerima perilaku seseorang dalam situasi tertentu. Dengan peran yang 
dimainkan seseorang dalam organisasi, akan terbentuk suatu komponen penting dalam hal identitas dan kemampuan orang itu untuk bekerja. Dalam hal ini, suatu organisasi harus memastikan bahwa peran-peran tersebut telah didefinisikan dengan jelas.

\section{Perlindungan Hukum}

Dalam kamus besar bahasa indonesia pengertian perlindungan adalah tempat berlindung, hal (perbuatan dan sebagainya) memperlindungi. Sedangkan Hukum menurut J.C.T Simorangkir dan Woerjono Sastropranoto adalah suatu peraturan-peraturan yang bersifat memaksa, yang menentukan tingkah laku manusia dalam lingkungan masyarakat yang dibuat oleh badan-badan resmi yang berwajib. Menurut R. Soeroso, hukum adalah himpunan peraturan yang dibuat oleh yang berwenang dengan tujuan untuk mengatur tata kehidupan bermasyarakat yang mempunyai ciri memerintah dan melarang serta mempunyai sifat memaksa denga menjatuhkan sanksi hukuman bagi yang melanggarnya. Sedangkan menurut Mochtar Kusumaatmaja, pengertian hukum yang memadai harus tidak hanya memandang hukum itu sebagai suatu perangkat kaidah dan asas-asas yang mengatur kehidupan manusia dalam masyarakat, tapi harus pula mencakup lembaga (institusi) dan proses yang diperlukan untuk mewujudkan hukum dalam kenyataan. Jadi, perlindungan hukum adalah suatu perlindungan yang diberikan kepada subyek hukum dalam bentuk perangkat hukum baik yang bersifat preventif maupun bersifat refresif, yang yang tertulis maupun tidak tertulis dengan kata lain perlindungan hukum sebagai suatu gambaran dari fungsi hukum, yaitu konsep dimana hukum dapat memberikan suatu keadilan, ketertiban, kepastian, kemanfaatan dan kedamaian.

\section{Saksi dan korban}

Menurut pasal 1 angka 26 kitab undang-undang hukum acara pidana, saksi adalah : “Orang yang dapat memberikan keterangan guna kepentingan penyidikan, penuntutan, dan peradilan tentang suatu perkara pidana yang ia dengar sendiri, ia lihat sendiri, dan ia alami sendiri ".

Menurut kamus Crime Dictionary yang dikutip seorang ahli (Abdussalam, 2010:5) bahwa Victim atau Korban adalah "orang yang telah mendapat penderitaan fisik atau penderitaan mental, kerugian harta benda atau mengakibatkan mati atas perbuatan atau usaha pelanggaran ringan dilakukan oleh pelaku tindak pidana dan lainnya". Disini jelas yang dimaksud "orang yang mendapat penderitaan fisik dan seterusnya" itu adalah korban dari pelanggaran atau tindak pidana.

\section{Konsep dan Dasar Perlindungan Saksi dan Korban}

Pada awalnya keberadaan saksi dan korban kuranglah diperhitungkan. Keselamatan baik untuk dirinya sendiri maupun keluarga pada kasus-kasus tertentu menjadi taruhannya atas kesaksian yang mereka berikan. Dalam KUHAP cenderung lebih memberatkan pemberian perlindungan kepada warga negara yang berstatus tersangka, terdakwa dan 


\section{Sibatile Jocurral}

Jurnal Ilmiah Bidang Sosial, Tkonomi, Budaya, Tekuologi, dan Pendidikan

terpidana. Pada tahun 2003, good will (iktikad baik) dari pemerintah untuk melakukan perlindungan terhadap saksi dan korban mulai tampak, tetapi baru sebatas pada kasus-kasus tertentu.

Perlindungan yang diberikannya pun hanya dalam bentuk Peraturan Pemerintah (PP), yaitu: PP No. 24 Tahun 2003 tentang Tata Cara Perlindungan terhadapaSaksi, Penyidik, Penuntut Umum, dan Hakim dalam Perkara Tindak Pidana Terorisme. Dan PP No. 57 Tahun 2003 tentang Tata Cara Perlindungan Khusus bagi Pelapor dan Saksi Tindak Pidana Pencucian Uang.

Barulah pada tahun 2006 pemerintah mengeluarkan peraturan perundang-undangan berupa Undang-Undang Nomor 13 Tahun 2006 tentang Perlindungan Saksi dan Korban yang di undangkan pada 11 Agustus 2006. Peranan saksi dan juga korban sangatlah penting dalam rangka untuk melahirkan sebuah keputusan yang adil dan obyektif. Untuk itulah perlindungan terhadap saksi dan korban menjadi sangat penting juga.

\section{Tindak Pidana}

Tindak Pidana atau Perbuatan pidana adalah perbuatan seseorang atau sekelompok orang yang menimbulkan peristiwa pidana atau perbuatan yang melanggar hukum pidana dan diancam dengan hukuman. Perbuatan pidana dibedakan menjadi beberapa macam, yaitu: Perbuatan pidana (delik) formal, adalah suatu perbuatan pidana yang sudah dilakukan dan perbuatan itu benar-benar melanggar ketentuan yang dirumuskan dalam Pasal undangundang yang bersangkutan. Delik material, adalah suatu perbuatan pidana yang dilarang, yaitu akibat yang timbul dari perbuatan itu. delik dolus, adalah suatu perbuatan pidana yang dilakukan dengan sengaja. delik culpa, adalah perbuatan pidana yang tidak disengaja. delik aduan, adalah suatu perbuatan pidana yang memerlukan pengaduan orang lain. delik politik, adalah delik atau perbuatan pidana yang ditujukan kepada keamanan negara baik secara langsung maupun tidak langsung.

\section{Korupsi}

Konsep Korupsi / Istilah "korupsi” berasal dari bahasa Latin yakni “corruptio”atau "corruptus" yangdisalin ke berbagai bahasa. Dalam bahasa Inggris, corruption atau corrupt, bahasaBelanda coruptie. Secara harfiah istilah tersebut diartikan sebagai keburukan, kebusukan,atau ketidak-jujuran. Istilah corruption dalam Black's Law Disctionary didefinisikan: (Henry Campbell Black; 1979 : 311.) “... an act done with an intent to give some advantage inconsistent with official duty and the rights of other. The act an official or fiduciary person who unlawfully and wrongfully uses his station or character to procure some benefit for himself or for another person, contrary to duty and the rights of others".

\section{METODE PENELITIAN}

Untuk melakukan suatu penelitian hukum maka harus menggunakan metode penelitian. Metode penelitian merupakan suatu cara atau jalan untuk memperoleh kembali 
pemecahan terhadap segala permasalahan. Dalam melakukan penelitian untuk penyusunan tesis dengan judul" Efektifitas Peran Lembaga Perlindungan Saksi Dan Korban (Lpsk) Dalam Melindungi Saksi Tindak Pidana Gratifikasi “, dibutuhkan data -data yang akurat untuk memperoleh data yang diperlukan dalam penyusunan tesis ini yang memenuhi syarat kualitas maupun kuantitas, maka digunakan metode penelitian tertentu.

Metode merupakan sarana untuk menemukan, merumuskan, menganalisa suatu masalah tertentu untuk mengungkap suatu kebenaran, karena metode pada prinsipnya memberikan pedoman tentang cara ilmuwan mempelajari, menganalisa serta memahami apa yang dipelajarinya. Penelitian merupakan suatu kegiatan ilmiah yang berusaha untuk memecahkan masalah-masalah secara sistematis dengan menggunakan metode-metode tertentu dan teknik - teknik tertentu. Kegiatan penelitian ini merupakan usaha untuk menganalisa serta mengadakan konstruksi secara metodologis. Sistematis adalah berdasarkan sistem tertentu dan konsisten, berarti tidak adanya hal-hal yang bertentangan dalam suatu kerangka tertentu. Penelitian merupakan suatu sarana pokok dalam pengembangan ilmu pengetahuan maupun teknologi. Hal ini disebabkan karena penelitian pada umumnya bertujuan untuk menemukan, mengungkapkan, mengembangkan, dan menguji kebenaran suatu pengetahuan secara sistematis, metodologis, dan konsisten. Menemukan berarti berusaha memperoleh sesuatu untuk mengisi kekosongan atau kekurangan. Mengembangkan berarti memperluas dan menggali lebih dalam sesuatu yang telah ada. Menguji kebenaran dilakukan jika apa yang sudah ada diragukan kebenarannya. Menurut Peter Mahmud Marzuki, penelitian hukum merupakan suatu proses ilmiah untuk mencari pemecahan atas isu hukum yang muncul dengan tujuan untuk memberikan perskripsi mengenai apa yang seyogyanya atas isu hukum yang muncul tersebut. Sehingga dapat dikatakan bahwa penelitian hukum adalah suatu proses menemukan aturan hukum, prinsip-prinsip hukum, maupun doktrin hukum guna menjawab isu hukum yang dihadapi. Metode penelitian dalam penulisan hukum ini terdiri dari: Metode Pendekatan, Metode Pengumpulan Data dan Metode Analisis Data.

\section{Metode Pendekatan}

Metode Pendekatan adalah lanjutan logis dari pendekatan untukmenguji hipotesa, melalui metoda pengujian statistik dengan sumber data yang diperoleh berdasarkan "rancangan percobaan" yang serasi untuk tujuan tersebut. Penelitian hukum pada dasarnya dapat dibedakan menjadi penelitian hukum normatif dan penelitian hukum sosiologis atau empiris. Penelitian hukum normatif mendasarkan hukum sebagai norma dengan metodenya bersifat doktrinal. Sedangkan penelitian hukum empiris memiliki maksud untuk mempelajari saja dan bukan mengajarkan suatu doktrin, sehingga metodenya bersifat nondoktrinal. Dalam penelitian hukum normatif, penelitian dilakukan dengan cara meneliti bahan pustaka atau data sekunder saja, sedangkan dalam penelitian hukum sosiologis penelitian dilakukan dengan meneliti data primer yang diperoleh langsung dari masyarakat (data dasar). Permasalahan pokok dalam penelitian ini adalah termasuk masalah dengan 


\section{Sibcitie gourral}

Jurnal Ilmiah Bidang Sosial, Thonomi, Budaya, Tekvologi, dan Pendidikan

E-ISSN8 $2809-8544$

permasalahan tentang efektifitas peran lembaga perlindungan saksidan korban dalam melindungi saksi tindak pidana gratifikasi. Oleh karena itupendekatannya tidak terlepas dari penelitian hukum dalam artikepustakaan (sekunder) dan peraturan perundang-undangan (primer). Dengan demikian dalam penelitian ini, peneliti akan menggunaan pendekatan yuridis normatif.

\section{Jenis dan Sumber Data}

Secara umum, maka didalam penelitian biasanya dibedakan antara data yang diperoleh secara langsung dari masyarakat (mengenai perilakunya; data empiris) dan dari bahan pustaka. Yang diperoleh langsung dari masyarakat dinamakan data primer atau data dasar dan dari bahan pustaka diberi nama data sekunder. Jenis data dalam penelitian ini adalah data sekunder, mengenai peraturan perundang-undangan dan dokumen-dokumen lain yang mendukung yang dapat diperoleh dari sumber-sumber kepustakaan tentang teori-teori hukum dan pendapat para ahli hukum.

\section{Spesifikasi Penelitian}

Penelitian ini bersifat deskriptif analitis yaitu menyajikan gambaran tentang efektifitas peran lembaga perlindungan saksi dan korban dalam melindungi saksi tindak pidana gratifikasi dan menganalisis permasalahan tersebut secara cermat dan objektif.

\section{Metode Pengumpulan Data}

Menurut Soerjono Soekanto dikenal ada tiga alat pengumpulan data dalam penelitian sebagai berikut: (1) Studi dokumen atau bahan pustaka, (2) Pengamatan atau observasi, (3) Wawancara atau Interview. Metode pengumpulan data yang digunakan dalam penulisan hukum ini pada dasarnya berhubungan langsung dengan metode pendekatan yang dipilih. Dikarenakan menggunakan pendekatan yuridis normatif, maka metode pengumpulan data dilakukan dengan jalan penelitian kepustakaan (library research). Dengan metode penelitian kepustakaan, data yang dikumpulkan serta digunakan sebagai bahan penelitian adalah datadata sekunder.

\section{Metode Analisis Data}

Data yang terkumpul melalui kegiatan tersebut diproses melalui pengolahan dan penyajian data dengan melakukan editing dimana data yang diperoleh diperiksa dan diteliti kembali tentang kelengkapan, kejelasan, dan kebenarannya. Dengan cara tersebut akan terhindar dari kekurangan dan kesalahan kemudian dilakukan evaluasi dengan memerksa ulang meneliti kembali data yang telah diperoleh, baik mengenai kelengkapan maupun kejelasan atas jawaban permasalahan yang ada. Selanjutnya penulis menganalisis data secara kualitatif, data yang diperoleh akan dianalisis secara kualitatif, yaitu suatu proses pengorganisasian dan penyusunan data ke dalam pola, kategori dan satu uraian sehingga ditemukan tema dan dapat ditarik suatu kesimpulan yang kemudian dipakai untuk mengkaji 
secara normatif tentangEfektifitas Peran Lembaga Perlindungan Saksi dan Korban (LPSK) Dalam Melindungi Saksi Tindak Pidana Gratifikasi, melalui metode yang bersifat deksriptif analitis. Metode ini dilakukan dengan cara mengguraikan gambaran dari data yang diperoleh dan menghubungkannya satu sama lain untuk mendapatkan kesimpulan dari permasalahan yang diteliti.

\section{HASIL PENELITIAN}

\section{Selayang Pandang Lembaga Perlindungan Saksi dan Korban di Indonesia}

Lembaga Perlindungan Saksi dan Korban (selanjutnya disebut LPSK) merupakan lembaga mandiri yaitu lembaga yang independent tanpa adanya campur tangan dari pihak manapun, lembaga ini berkedudukan di Ibukota Negara Republik Indonesia. UndangUndang Perlindungan Saksi dan Korban (selanjutnya disebut UU PSK), menyatakan bahwa LPSK adalah lembaga yang mandiri adalah sebuah lembaga yang independen (biasanya disebut sebagai komisi independen), yakni organ negara (state organs) yang di idealkan independen dan karenanya berada di luar cabang kekuasaan baik Eksekutif, Legislatif maupun Judikatif, namun memiliki fungsi campuran antar ketiga cabang kekuasaan tersebut. Dalam berbagai kepustakaan, yang dimaksud dengan independen adalah: (1) berkaitan erat dengan pemberhentian anggota komisi yang hanya dapat dilakukan berdasarkan sebab-sebab yang diatur dalam undang-undang pembentukan komisi yangbersangkutan, tidak sebagaimana lazimnya komisi negara biasa yang dapat sewaktu-waktu diberhentikan oleh presiden karena merupakan bagian dari eksekutif (2) bila dinyatakan secara tegas oleh kongres dalam undang-undang komisi yang bersangkutan atau bila Presiden dibatasi untuk tidak secara bebas memutuskan (discretionary decesion) pemberhentian pimpinan komisi.(3)Sifat independen juga tercermin dari kepemimpinan yang kolektif, bukan hanya seorang pimpinan (4) kepemimpinan tidak dikuasai/mayoritas berasal dari partai politik tertentu dan (5) masa jabatan pemimpin komisi tidak habis secara berrsamaan, tetapi bergantian (starggerd terms).

Karena merupakan lembaga yang mandiri maka kemudian Undang-Undang Perlindungan Saksi dan Korban tidak meletakkan struktur LPSK berada di bawah instansi manapun baik instansi pemerintah (eksekutif) maupun lembaga negara lainnya. Walaupun dari segi finansial lembaga ini didukung sepenuhnya dari keuangan negara. Pilihan UU terhadap model lembaga seperti ini tentunya menyerupai berbagai lembaga negara yang telah ada seperti: Komnas HAM, KPK, PPATK dan lain sebagainya. Pertanyaanya adalah apa yang menjadi pertimbangan dari para perumus UU untuk menetapkan model lembaga seperti ini. Dari berbagai dokumen yang ada, keputusan untuk memilih model lembaga ini terkait dengan beberapa argumentasi. Pertama, keinginan untuk membuat lembaga yang secara khusus mengurusi masalah perlindungan saksi dan korban yang tidak berada di bawah institusi yang sudah ada, yakni kepolisian atau kejaksaan, Komnas HAM atau Departemen Hukum dan HAM. Kedua, karena institusi yang lainnya sudah memiliki beban tanggungjawab yang besar, oleh karena itu jangan sampai program perlindungan membebani 


\section{Sibcitie gournal}

Jurnal Ilmiah Bidang Sosial, Tkonomi, Budaya, Tekuologi, dan Pendidikan

lagi lembaga-lembaga tersebut.Menurut Bagin Manan ada lima fungsi kekuasan kehakiman dalam penyelenggaraan negara yang salah satunya berbunyi "kekuasaan kehakiman berfungsi melindungi dan menegakkan hak asasi manusia:" Menurut pendapat Zain Badjeber dalam pasal 24 ayat (3) UUD 1945 yang ditegaskan dalam ketentuan pasal 38 UU Nomor 48 tahun 2009 Bab V tentang Kekuasaan Kehakiman, "tidak hanya kepolisian dan kejaksaan advokat dan Lembaga Pemasyarakatan yang menjadi bagian dari badan-badan lain yang fungsinya terkait dengan penegakan hukum, pelayanan hukum dan administrasi hukum yang dimaknai juga termasuk didalamnya LPSK sebagai (independen bodies). Bila kita bandingkan dengan beberapa model lembaga perlindungan saksi di beberapa negara, maka kedudukan lembaga perlindungan saksinya berada di bawah supervisi dari intansi tertentu. Amerika Serikat misalnya, program perlindungan saksi (WITSEC) berada di bawah Departement of Justice yang dipimpin oleh Jaksa Agung, yang ditujukan untuk mempermudah akses dan koordinasin. Afrika Selatan, juga membuat model yang hampir sama. Sedangkan Kanada meletakan program perlindungan saksi dibawah Jaksa Agung yang dikelola oleh komisioner. Inggris memiliki program perlindungan saksi yang berada dalam struktur kepolisian negara bagian, dan juga ada dalam struktur kepolisian federal, demikian juga dengan program perlindungan saksi di Jerman yang berada dalam struktur kepolisian yang disebut sebagai zeugenschuttzdienststelle (unit perlindungan saksi).

\section{Efektivitas Peran Lembaga Perlindungan Saksi dan Korban (LPSK) dalam Melindungi Saksi Tindak Pidana Gratifikasi}

Kepercayaan publik terhadap Lembaga Perlindungan Saksi dan Korban (LPSK) selama satu periode (tahun 2008 - 2013), dalam melindungi saksi tindak pidana korupsi (khususnya gratifikasi) dinilai masih sedikit. tidak seperti pelanggaran HAM yang lebih banyak jumlah permohonannya.

Menurut penulis, hal tersebut dimungkinkan kurangnya kepekaan, kewaspadaan dan kepercayaan masyarakat dalam memperoleh perlindungan dari LPSK untuk terhindar dari ancaman dari pihak yang di duga melakukan tindak pidana gratifikasi ketika hendak menjadi saksi/ pelapor. Padahal potret ancaman dan intimidasi terhadap saksi gratifikasi kian masif. Seperti terjadi pada kasus pemecatan Djaja Budi Suhardja, setelah bersaksi kasus dugaan gratifikasi pengadaan alat kesehatan oleh atasannya sendiri. Menurut penulis hal ini sangat merugikan bagi saksi sebagai pelapor dan akan membuat berpikir dua kali bagi orang yang bakal ingin menjadi saksi pelapor. Dalam keadaan dilema yang seperti itulah di harapkan LPSK mampu mengayomi dan memberikan kepastian perlindungan sehingga mampu meyakinkan saksi/ pelapor jauh dari ancaman dan intimidasi. Seperti yang ditentukan dalam Pasal 39 UU PSK menyatakan "setiap orang yang menyebabkan saksi dan/ atau korban atau keluarganya kehilangan pekerjaan karena saksi dan/ atau korban tersebut memberikan kesaksian yang benar dalam proses peradilan, dipidana dengan pidana penjara paling singkat 2 (dua) tahun dan paling lama 7 (tujuh) tahun dan dipidana denda paling sedikit Rp. 
80.000.000 (delapan puluh juta rupiah) dan paling banyak Rp.500.000.000 (lima ratus juta rupiah).

\section{Upaya Ideal Peran Lembaga Perlindungan Saksi dan Korban ( LPSK) Dalam Melindungi Saksi Tindak Pidana Gratifikasi Di Masa Yang Akan Datang.}

Ketika melihat kembali berbagai kendala-kendala LPSK pada penjelasan di atas, di dalam mewujudkan Efektivitas Peran sebagai Lembaga Perlindungan Saksi dan Korban (LPSK) dalam melindungi saksi tindak pidana gratifikasi, jika mengadopsi Peran Lembaga Perlindungan Saksi di Amerika Serikat, Afrika Selatan, dan Jerman. Menurut penulis perbedaan Lembaga Perlindungan Saksi di Amerika Serikat dengan Lembaga Perlindungan saksi di Indonesia dalam mengkualifikasikan seseorang menjadi saksi yang patut dilindungi, kemudian cara/ syarat memberikan perlindungan dan bentuk-bentuk perlindungan tidak jauh berbeda dengan di Indonesia. Namun di Indonesia Lembaga Perlindungan saksi dalam kerjasamanya belum maksimal berkoordinasi dengan lembaga penegak hukum lainnya yang dianggap berkompeten dalam perlindungan hukum, sedangkan di Amerika sangat koordinatif sesama lembaga penegak hukum dalam memberikan jaminan perlindungan terhadap saksi meski dalam permohonan perlindungannya sangat rumit. Akan tetapi menurut penulis kelemahan perlindungan saksi di Amerika Serikat adalah pemberian perlindungan terbatas pada saksi yang dianggap saksi kunci saja sedangkan di Indonesia semua kualifikasi saksi patut dilindungi baik dalam keadaan darurat ataupun tidak. Di Indonesia belum ada aturan yang jelas ketika seseorang yang hendak menjadi saksi dan dianggap darurat untuk dilindungi dari ancaman sebelum penyidikan dan sesudah memberikan keterangan dipengadilan dalam jangka waktu sampai kapan saksi masih mendapatkan perlindungan. Kemudian Lembaga Perlindungan saksi di Afrika Selatan dalam segala kegiatannya terpusat pada satu komando saja yaitu direktur. Segala bentuk kualifikasi saksi, pelaksanaan dan bentuk-bentuk perlindungan dapat di amandemen sesuai keperluan direktur. Dalam bentuk perlindungan saksi berjangka waktu sementara tidak lebih dari 14 hari, hal ini tidak diatur dalam Undang-Undang Nomor 13 tahun 2006 tentang perlindungan saksi dan korban di indonesia.Di Afrika Selatan di dalam pemberian perlindungan hukum orang terkait (keluarga saksi atau orang dekat saksi) yang dilindungi wajib membayar finansial yang bukan merupakan kewajiban direktur, sementara di Indonesia tidak mengatur secara jelas tentang kewajiban membayar finasial yang bukan tanggung jawab LPSK. Seperti pada pasal 5 huruf "m" UU No. 13 tahun 2006 tentang perlindungan saksi dan korban yang berbunyi "seorang saksi dan korban berhak memperoleh bantuan biaya hidup sementara sampai batas perlindungan berakhir", hal ini Cuma menjelaskan secara umum bantuan apa yang wajib didapatkan saksi dan orang terkait yang memperoleh perlindungan, tidak secara spesifik bentuk apa bantuannya. Menurut penulis kelemahan lain yang berhubungan dengan perbandingan perlindungan saksi di Afrika Selatan adalah Undang-Undang No. 13 tahun 2006 tentang perlindungan saksi dan korban tidak mengatur tentang bagaimana LPSK memberi kewajiban bagi saksi dalam proses perlindungannya, terlepas dari memberi 


\section{Sibcitie gournal}

Jurnal Ilmiah Bidang Sosial, Tkonomi, Budaya, Tekuologi, dan Pendidikan

kesaksian dipengadilan saja. Kemudian letak perbedaan Hak saksi di Jerman dengan Indonesia yang diberikan oleh lembaga perlindungan saksi, dalam Pasal 5 Undang-Undang Nomor 13 tahun 2006 tentang perlindungan saksi yang mengatur tentang Hak saksi di Indonesia tidak mengatur pemeriksaan secara terpisah antara saksi dan terdakwa. Padahal hal ini sangat berpengaruh terhadap keadaan psikologis saksi pada saat pemeriksaan, apabila kehadiran tersangka (tersangka memilik hak untuk hadir pada saat pemeriksaan "pasal 247 ayat (2) KUHAP Jerman") pada saat pemeriksaan berlangsung dalam keadaan yang trauma atau keadaan terancam atau diancam secara langsung bisa saja saksi tidak memberikan kesaksiannya (right to refuse to give evidence). Kemudian pemeriksaan dengan rekaman kamera belum secara jelas diatur dalam Pasal 9 ayat (3) Undang-Undang Nomor 13 tahun 2006 tentang Perlindungan Saksi dan Korban yang berbunyi "saksi dan/ atau korban sebagaimana dimaksud pasal ayat (1) dapat pula didengar kesaksiannya melalui sarana elektronik dengan didampingi oleh pejabat berwenang".

\section{PENUTUP}

Efektivitas Peran Lembaga Perlindungan Saksi dan Korban (LPSK) dalam melindungi Saksi tindak pidana gratifikasi belum maksimal, disebabkan kurangnya sosialisasi di masyarakat khususnya didaerah-daerah tentang keberadaan Lembaga Perlindungan Saksi dan Korban sebagai lembaga yang bertugas melindungi saksi. Banyaknya saksi/pelapor gratifikasi yang kurang mengetahui prosedur permohonan perlindungan, belum adanya kantor Lembaga Perlindungan Saksi dan Korban yang dibentuk di daerah-daerah sehingga memperlambat proses pelayanan perlindungan terhadap saksi/ pelapor tindak pidana gratifikasi , kurangnya kerjasama antara lembaga penegak hukum dalam hal perlindungan saksi tindak pidana gratifikasi, terbatasnya tugas dan wewenang Lembaga Perlindungan Saksi dan Korban dalam Undang-Undang Nomor 13 tahun 2006 Tentang Perlindungan Saksi dan Korban. Upaya Ideal Efektifitas Peran Lembaga Perlindungan Saksi dan Korban Dalam Melindungi Saksi Tindak Pidana Gratifikasi dimasa mendatang adalah dari segi substansinya merancang dan mengajukan usulan ke Lembaga Legislatif tentang rumusan dan penjelasan Undang-Undang Perlindungan Saksi dan Korban Nomor 13 tahun 2006 diantaranya Pasal 1 ayat (1) yang menyangkut saksi dan mengatur tentang Saksi Gratifikasi pada bagian tersendiri, Pasal 5 tentang hak saksi dalam pemeriksaan terpisah dengan terdakwa , Pasal 29 sampai Pasal 31 direvisi agar permohonan dan persetujuan saksi gratifikasi tidak dalam proses yang lama, jaminan pemberian perlindungan terhadap saksi tindak pidana gratifikasi tidak hanya dalam proses peradilan saja, melainkan juga setelah proses peradilan selesai. Strukturnya ialah LPSK lebih meningkatkan sinergitas dan kerjasama terhadap lembaga penegak hukum, instansi pemerintah terkait, ormas, pihak swasta dan masyarakat baik dalam melindungi saksi/pelapor tindak pidana gratifikasi maupun mendapatkan informasi dari saksi/pelapor dugaan tindak pidana gratifikasi. Kulturnya ialah adanya sosialisasi tentang eksistensi LPSK khususnya dalam melindungi saksi tindak pidana gratifikasi sehingga menumbuhkan 
kepercayaan masyarakat terhadap kepastian perlindungan yang jauh dari ancaman dan intimidasi bagi saksi/pelapor tindak pidana gratifikasi.

\section{DAFTAR PUSTAKA}

Anneka Saldian Mardhiah, Pentingnya Lembaga Perlindungan Saksi dan Korban (LPSK) di Negara ber-Bhinneka Tunggal Ika ini, Hlm. 2.

Ahmad Warson Al- Munawir, 1997, Kamus Al-Munawir, Ed. 2, Pustaka Progresif, Yogyakarta, Hlm 746.

Andi Hamzah, 2012 , Pemberantasan Korupsi Melalui Hukum Pidana Nasional dan Internasional, Cet 5, Rajawali Pers , Jakarta, Hlm. 10

Askari Razak, dkk, 2013, Memperkuat LPSK, Mengembalikan Wibawa Hukum, LPSK, Jakarta, Hlm 4.

Aziz Syamsuddin, 2011, Tindak Pidana Khusus, Sinar Grafika, Jakarta, Hlm. 15.

Bahder Johan Nasution, 2011, Negara Hukum dan Hak Asasi Manusia, Mandar Maju, Cet.

I. Bandung, Hlm. 258.

Barda Nawawi Arief, 2012 , Reformasi Sistem Peradilan (Sistem Penegakan Hukum) di Indonesia, cet 3, Badan Penerbit Universitas Diponegoro, Semarang. Hlm. 9-10.

Bambang Waluyo, 2011, Viktimologi Perlindungan Korban \& Saksi, Sinar Grafika, Jakarta.

Burhan Asshofa, 2001, Metode Penelitian Hukum, Rineka Cipta, Jakarta.

Chaeruddin, Syaiful Ahmad Dinar dan Syarif Fadilah, 2009, Tindak Pidana Korupsi (strategi pencegahan dan penegakan hukum), Reflika Aditama, Bandung, Hlm.2.

Darji Darmodiharjo \& Shidarta, 2006, Pokok-Pokok Filsafat Hukum : Apa dan Bagaimana Filsafat Hukum Indonesia, PT. Gramedia Pustaka Utama, Jakarta.

Didiek Ahmad Supadie, dkk, 2012, Studi Islam I, Cet. VII, LKPI Unissula, Semarang, Hlm. 17

Ermansjah Djaja, 2010, Memberantas Korupsi Bersama KPK, Cet . 1, Sinar Grafika, Jakarta, Hlm. 12

Evi Hartanti, 2006, Tindak Pidana Korupsi, Cetakan Kedua, Sinar Grafika, Jakarta, Hlm.9.

Hari Sasangka, Lily Rosita, 2003,Hukum Pembuktian Dalam Perkara Pidana, Mandar Maju, Bandung;

H.L.A Hart, 2011, The Concept Of law (Konsep Hukum, diterjemahkan oleh M.Khozim), Cet. V, Nusa Media, Bandung, Hlm. 43.

Ibnul Hamman, Sarah Fathul Qodir, dalam Daimatul Ihsan, 2010 , Pandangan Hukum Islam Terhadap Perlindungan Saksi dan Korban Dalam Perkara Pidana, Skripsi, Hlm. 15.

Jawade Hafidz Arsyad, Korupsi Dalam Perspektif HAN (Hukum Administrasi Negara), Sinar Grafika, Jakarta, 2013, Hlm 15.

Joko Subagyo, Metode Penelitian Dalam Teori Dan Praktek, 2006, Rineka Cipta, Jakarta. Komisi Pemberantasan Korupsi (KPK), 2006, Memahami Untuk Membasmi (Buku Saku Untuk Memahami Tindak Pidana Korupsi), KPK, Jakarta, Hlm. 95. 


\section{Sibatile Jocurral}

Jurnal Ilmiah Bidang Sosial, Ekonomi, Budaya, Tekuologi, dan Pendidikan

Lukman Ali. 1991. Kamus Besar Bahasa Indonesia. Jakarta: Balai Pustaka. Hal.566.

"Pelapor adalah orang yang melaporkan".

Michael R. Asimow dalam Administratif Law, 2002. Berdasarkan keputusan Mahkamah

Agung Amerika Serikat dalam perkara Humprey's Executor v. United States

M. Akil Mochtar,2006, Memberantas Korupsi Efektivitas Sistem Pembalikan Beban Pembuktian dalam Gratifikasi, Q-Communication, Jakarta.

M. Arief Amrullah, 2007, Politik Hukum Pidana Dalam Perlindungan Korban Kejahatan Ekonomi di Bidang Perbankan, Cet. II, Bayumedia Publishing, Malang, Hlm. 13.

Muhammad Ali, 2001, Kamus Lengkap Bahasa Indonesia Modern, Pustaka Amani Jakarta, Hlm.13.

M. Nurul Irfan. 2011, Korupsi Dalam Hukum Pidana Islam, AMZAH, Jakarta, Hlm. 146147.

M.Zun-Nun Tuhepaly, Pengertian Gratifikasi, Blog, 2013, hlm.1.

Martiman Prodjohamidjojo,2011, Penerapan Pembuktian Terbalik Dalam Kasus Korupsi, Maju Mandar, Bandung.

Muhadar, Edi Abdullah \& Husni Tamrin, 2009, Perlindungan Saksi dan Korban Dalam Sistem Peradilan Pidana, CV. Putra Media Nusantara, Surabaya, Hlm. 2.

Mujahid A Latief, dkk (Peneliti KHN), 2010, Kebijakan Reformasi Hukum Suatu Rekomendasi Jilid 1 \& 2, Tim Penerbit KHN, Jakarta, Hlm. 51.

Peter Mahmud Marzuki, 2010, Penelitian Hukum, Kencana, Jakarta.

Philipus M. Hardjon, Menulis Laporan Penelitian Hukum, (Surabaya: Unair, 1999), hlm. 2, sebagaimana dikutip dalam Hadin Muhjad dan Nunuk Nuswardani, Penelitian Hukum Indonesia Kontemporer, (Yogyakarta: Genta Publishing, 2012).

Philipus M. Hadjon, 2006, Perlindungan Hukum Bagi Rakyat di Indonesia, Bina Ilmu, Surabaya, Hlm. 2

Ruswiati Surya Saputra, 2006 , Negara Tidak Boleh Meniadakan Suatu Standar HAM, Perlindungan Hak Asasi Bagi Kelompok Khusus terhadap Diskriminasi dan Kekerasan, PTIK Press Restu Agung, Jakarta, Hlm. 10.

R. Deda Suwandi, 2011, Tips dan Trik Menghadapi Kasus Hukum, Delta Publishing, Semarang, Hlm. 4-5.

R.Subekti, 1994, Perlindungan Hak Asasi Manusia Dalam KUHAP, Cet 2, Pradya Paramita, Jakarta, Hlm. 4.

Ronny Hanitjo Soemitro, 1982, Metodologi Penelitian Hukum, Ghalia Indonesia, Jakarta. Rocky Marbun, Cerdik \& Taktis Menghadapi Kasus Hukum, Visimedia, Jakarta, 2009, hlm. 86.

RS Harum Pudjianto, 1994, Politik Hukum Undang-Undang Pemberantasan Tindak Pidana Korupsi di Indonesia. Universitas Atma Jaya, Yogyakarta.

Siswanto Sunarso, 2012, Viktimologi dalam Sistem Peradilan Pidana, Sinar Grafika, Jakarta, hlm. 305.

Soerjono Soekanto, 1984, Pengantar Penelitian Hukum, UI Press, Jakarta. 
Sri Endah Wahyuningsih, 2013, Prinsip-prinsip Individualisasi Pidana Dalam Hukum Pidana Islam dan Pembaharuan Hukum Pidana Indonesia, Cet. II, Badan Penerbit Undip, Semarang, Hlm. 5.

Sri Sumarwani , 2012, Sejarah Perundang-Undangan Tindak Pidana Korupsi Sebelum UU No 3 Tahun 1971 sampai dengan UU Nomor 20 Tahun 2001, UNDIP Press,Semarang.

Sri Sumarwani, 2012, Pemidanaan Tindak Tindak Pidana korupsi dari waktu ke waktu, UNDIP Press, Semarang.

Supriyadi Widodo Eddyono,2007, Seri Position Paper Perlindungan Saksi dan Korban,Lembaga Perlindungan Saksi dan Korban di Indonesia: Sebuah Pemetaan Awal,cetI,Indonesia Corruption Watch (ICW), Jakarta, Hlm. 12-13.

Supriyadi Widodo Eddyono, UU Perlindungan Saksi belum progresif, ELSAM \& Koalisi Perlindungan Saksi, 2006.

Syed Hussein Alatas, 1983, Sosiologis Korupsi, Sebuah Penjelajahan Dengan Data Kontemporer, LP3ES, Jakarta, h.12.

William F. Funk dan Richard H. Seamon, 2001, dalam Administratif Law: Example \& Explanation, Hlm7.

Wojowasito. S. Poerwodarminto W.J.S, Kamus Lengkap Inggris-Indonesia, IndonesiaInggris, Hasta Bandung, Hlm.43.

Yahya Ahmad Zein, 2012, Problematika Hak Asasi Manusia, Edisi Pertama. Cetakan Pertama, Liberty. Yogyakarta. Hlm. 50.

Yusuf Al Qardhawy, 2007, Fiqhi Prioritas Sebuah Kajian Baru Berdasarkan Al-Quran dan As-Sunnah, Robbani Press, Jakarta. Hlm. 12 